\title{
Neonchocotyle violantei n. sp. (Monogenea, Hexabothriidae) from Pseudobatos lentiginosus (Rhinopristiformes, Rhinobatidae) of Yucatán, Gulf of Mexico
}

\author{
Neonchocotyle violantei n. sp. (Monogenea, Hexabothriidae) do Pseudobatos lentiginosus \\ (Rhinopristiformes, Rhinobatidae) de Yucatán, Golfo do México \\ Guadalupe Quiterio-Rendon ${ }^{1}$; Scott Monks ${ }^{1,2}$; Griselda Pulido-Flores ${ }^{1,2 *}$

\begin{abstract}
${ }^{1}$ Laboratorio de Morfología Animal, Centro de Investigaciones Biológicas, Universidad Autónoma del Estado de Hidalgo, Pachuca, Hidalgo, México

${ }^{2}$ Research Fellow, Harold W. Manter Laboratory of Parasitology, University of Nebraska-Lincoln, Lincoln, Nebraska, United States
\end{abstract}

Received September 5, 2017

Accepted November 21, 2017

\begin{abstract}
Neonchocotyle violantei n. sp. (Monogenea: Hexabothriidae) infects the gill of the Atlantic guitarfish, Pseudobatos lentiginosus (Rhinopristiformes, Rhinobatidae) from littoral waters of Celestún, Yucatán, Mexico. It is assigned to Neonchocotyle because it has, among other features, an asymmetrical haptor, a seminal receptacle, a smooth oötype, and an egg with two elongate filaments. It differs from Neonchocotyle pastinacae, the only congener, by having a small body ( 821 long by 315 wide, length to width $=2.6: 1$ ), two pairs of microhooks between the haptoral appendix suckers, extracaecal (submarginal) vaginal pores, and 5-9 testes. This is the first record of a species of Neonchocotyle in the Gulf of Mexico, the first monogenean reported from P. lentiginosus in Mexico and the second species of Hexabothriidae reported from Mexico.
\end{abstract}

Keywords: Neonchocotyle sp. n., Pseudobatos lentiginosus, helminth, key.

\section{Resumo}

Neonchocotyle violantei n. sp. (Monogenea: Hexabothriidae) infecta brânquia de Pseudobatos lentiginosus, (Rhinopristiformes, Rhinobatidae) de águas litorâneas ao largo da costa de Celestún, Yucatán, México. É atribuído a Neonchocotyle porque tem, entre outras características, um haptor assimétrico, um receptáculo seminal, um tipo oótipo liso e um ovo com dois filamentos alongados. Difere de Neonchocotyle pastinacae, o único congênere, por ter um corpo pequeno (821 de comprimento por 315 de largura, comprimento a largura =2,6: 1), dois pares de microganchos entre as ventosas do apêndice haptoral, poros vaginais extracaecais (submarginal) e 5-9 testículos. Este é o primeiro registro de uma espécie de Neonchocotyle no Golfo do México, o primeiro monogenético registrado em P. lentiginosus no México e a segunda espécie de Hexabothriidae relatada no México.

Paravras-chave: Neonchocotyle sp. n., Pseudobatos lentiginosus, helminto, chave.

\section{Introduction}

Hexabothriidae Price, 1942 (Monogenea) includes 16 genera and approximately 77 species, although recent authors do not agree on those numbers (BOEGER \& KRITSKY, 1989, 13 genera; PATELLA \& BULLARD, 2013; KHEDDAM et al., 2016, 15), often not including Pristonchocotyle Watson \& Thorson, 1976. Members of the family infect the gills of Chondrichthyes (BOEGER \& KRITSKY, 1989). As part of a collaborative study

*Corresponding author: Griselda Pulido-Flores. Laboratorio de Morfología Animal, Centro de Investigaciones Biológicas, Universidad Autónoma del Estado de Hidalgo, Apartado Postal 1-10, C.P. 42001 Pachuca, Hidalgo,

México. e-mail: gpflores6@hotmail.com of helminths of marine fishes of the Gulf of Mexico, specimens of a monogenean similar to the only known species of Neonchocotyle Ktari \& Maillard, 1972, N. pastinacae Ktari \& Maillard, 1972 (Hexabothriidae) were collected from an Atlantic guitarfish, Pseudobatos lentiginosus (Garman, 1880) (Rhinopristiformes, Rhinobatidae). However, $N$. pastinacae was described from Dasyatis pastinaca (Linnaeus, 1758) (Dasyatidae), Gulf of Tunis.

An individual of Pseudobatos lentiginosus (= Atlantic guitarfish) was collected by a local fisherman in littoral waters of Celestún, Yucatán, Mexico, adjacent to the Reserva de la Biósfera Ría Celestún Ramsar site no. 1333. The region around Ría Celestún supports diverse habitats that have been minimally disturbed. The infected 
guitarfish was collected from the shallow marine platform nearby the mouth of the river and the costal lagoons (Ficha Informativa de los Humedales de Ramsar, Reserva de la Biosfera Ría Celestún. Given the magnitude of biodiversity of this region (CIUDAD DE MÉXICO, 2000), the discovery of a new species of Hexabothriidae is unsurprising; this species is described herein and the genus amended to include previously undocumented characters.

\section{Materials and Methods}

One Atlantic guitarfish was collected by a local fisherman using a long line in littoral waters of Celestún, Yucatán (2051'33”N; $\left.90^{\circ} 24^{\prime} 00^{\prime \prime W}\right)$, Gulf of Mexico, in February 1999. The external body surface of the guitarfish was examined using a magnifying glass. Each gill arch was excised, placed in a Petri dish with seawater, and examined using a stereomicroscope. Monogeneans, dead at the time of collection, were removed from gill lamellae and transferred temporarily to dishes containing seawater. When all worms had been collected, they were fixed with Alcohol-Formalin-Acetic Acid (AFA) at room temperature for at least $12 \mathrm{~h}$, and transferred for storage to $70 \%$ ethyl alcohol following Pulido-Flores \& Monks (2005). Specimens were stained with Gomori's trichrome, Mayer's carmalum, or Delafield's hematoxylin, dehydrated in an ethanol series, cleared in methyl salicylate, and mounted individually on slides in Canada balsam. Specimens were examined using a compound optical microscope equipped with differential interference contrast (DIC or Nomarski) optics, and drawings were made with the aid of a drawing tube. Measurements were made using an ocular micrometer; all measurements are given in micrometers as the mean followed in parentheses by the range and the number of structures measured. The numeration of the sucker complexes is according to Boeger \& Kritsky (1989) and measurements of sclerites follow Vaughan \& Christison (2012); only shaft length (from points h-i) and shaft width (from e-f) are reported herein (see VAUGHAN \& CHRISTISON, 2012; figures 1C, 1B, respectively). Measurements of some structures of $N$. pastinacae were estimated from the figures of Ktari \& Maillard (1972) because type materials (MNHN-Paris 52166) from the Muséum National d'Histoire Naturelle de Paris could no be located by the Museum. Names for standard shapes of structures are taken from Clopton (2004). Statistical analysis of variance (ANOVA) was used to assess differences in the sizes of suckers and sclerites, respectively, of the new species. Helminths were identified using existing taxonomic keys and published literature (PRICE, 1942; YAMAGUTI, 1963; KTARI \& MAILLARD, 1972; EUZET \& MAILLARD, 1974; BOEGER \& KRITSKY, 1989; BULLARD \& DIPPENAAR, 2003). Specimens were deposited in the Colección Nacional de Helmintos, Instituto de Biología, Universidad Nacional Autónoma de México, Mexico city, Mexico (CNHE) and the Harold W. Manter Laboratory of Parasitology, University of Nebraska State Museum, Lincoln, Nebraska (HWML).

\section{Results}

Family Hexabothriidae Price, 1942 (sensu BOEGER \& KRITSKY, 1989)

Genus Neonchocotyle Ktari \& Maillard, 1972
Type species Neonchocotyle pastinacae Ktari \& Maillard, 1972 ex. Dasyatis pastinaca (Linnaeus, 1758) (Myliobatiformes, Dasyatidae).

Emended diagnosis. With characters of Hexabothriidae (sensu BOEGER \& KRITSKY, 1989). Body elongate narrowly eliptoid to narrowly deltoid; tegument lacking papillae. Haptor asymmetrical, wider than body (Figures 1A), with 3 paired sucker-sclerite complexes; longitudinal haptoral axis forming an angle of approximately $45^{\circ}$ from midline of body; see correct orientation in Figure 1A). Sucker-sclerite complexes similar in form; each sclerite comprising a C-shaped shaft embedded in sucker wall with distal end having pointed tip. Dorsal haptoral appendix armed with 2 suckers; hamuli present or absent; microhooks present or absent. Two anterior glands present or absent; if present one on each side, having ducts continuing to pores at anterior margin of body. Ceca bifurcate, extending posteriorly from anterior end of body; lateral branches having diverticula extending lateral; ceca becoming confluent posterior to testes, extending posterior to form single blind-ending branch extending into haptor. Number of testes 8 to approximately 30 , slightly longer than wide, intercecal, oval to spherical, seminal vesicle present. Male copulatory organ enveloped by a pouch, with terminal end sclerotized or not; divided into proximal and distal portions. Proximal region of copulatory organ muscular; distal region narrow, surrounded by pars prostatica. Two vaginae present, parallel, having proximal and distal portions; proximal region connecting to vitelline reservoir, glandular and muscular distal region connecting to vaginal pore. Vaginal pores ventral, associated with encircling muscle, lateral to proximal portion of male copulatory organ, posterior to cecal bifurcation. Ovary tubular, deeply lobed, with ascending and descending branches; ascending branch dextral, sinuous, reaching to region of oviduct, descending branch coiled, connected posteriorly to oötype. Ö̈type, dorsal to ovary, ventral to vas deferens, leading to uterus. Seminal receptacle present. Transverse vitelline ducts dorsal, forming Y-shaped reservoir; proximal region of vaginae connected to anterior branches of reservoir and posterior region of reservoir join to oviduct (see KTARI \& MAILLARD, 1972, Figure 12). Eggs with two elongate filaments.

Type species. Neonchocotyle pastinacae Ktari \& Maillard, 1972

Neonchocotyle violantei $\mathrm{n}$. sp.

(Figures 1-4).

Type material. Holotype CNHE-10552; paratypes CNHE-10553, HWML-139359.

Other material examined. Callorhynchocotyle marplatensis Suriano \& Incorvaia, 1982 (HWML-20705); Dasyonchocotyle sp. (HWML-17206); Dasyonchocotyle dasyatis (Yamaguti, 1968) Boeger \& Kritsky, 1989 (CNHE-9361, HWML-75115); Erpocotyle microstoma (Brooks, 1934) Yamaguti, 1963 (HWML-1437); Erpocotyle tiburonis (Brooks, 1934) (HWML-1366); Heteronchocotyle leucas Hargis, 1955 (HWML-1443); Hexabothrium canicula (Cerfontaine, 1899) (HWML-1408); Paraheteronchocotyle amazonensis Mayes, Brooks \& Thorson 1981 (HWML-21391); Rajonchocotyle wehri Price, 1942 (HWML-1447); Rhinobatochoncotyle ciclovaginatus Doran, 1953 (HWML-31195); Squalonchocotyle microstoma Brooks, 1934 (= Erpocotyle microstoma [Brooks, 1934] YAMAGUTI, 1963) (CNHE-318); S. tiburonnis (= Erpocotyle tuburonis [Brooks, 1934] YAMAGUTI, 1963) (HWML-1366).

Type-host. Pseudobatos lentiginosus (Garman, 1880) (=Atlantic guitarfish) (Rhinopristiformes, Rhinobatidae). 


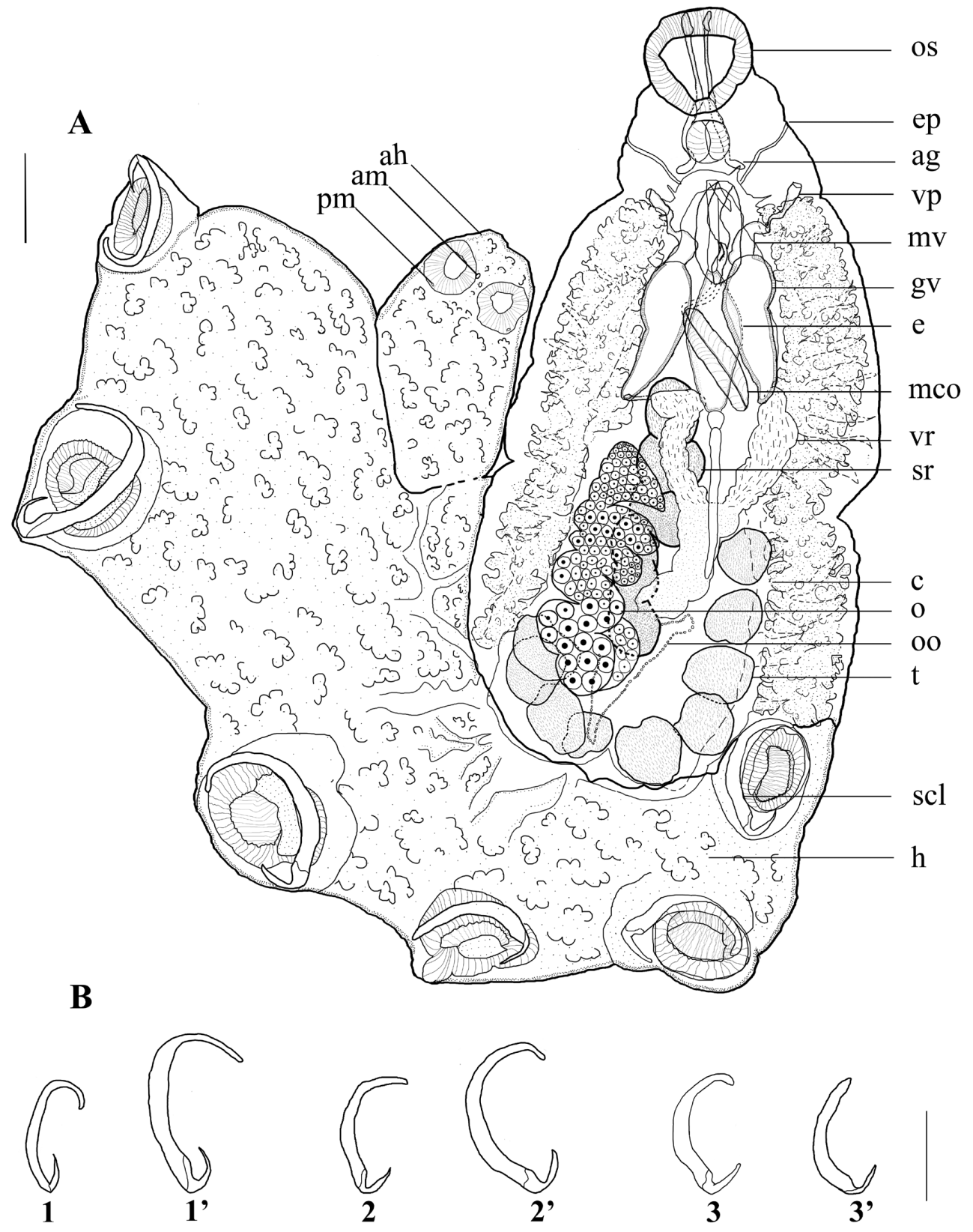

Figure 1. Neonchocotyle violantei n. sp. (A) holotype, ventral view; (B) detail of the sclerites of the haptoral sucker. Small numbers identify respective sclerites; sclerites pares are indicated by numbers 1 to 3, and 1' (1-prime) to 3' (3-prime) (see BOEGER \& KRITSKY, 1989). Scale bars: A, B = $75 \mu \mathrm{m}$. Abbreviations: ag, anterior glands; ah, dorsal haptoral appendix; am, anterior microhook; c, ceca; ep, excretor pore; gv, glandular portion of vagina; h, haptor; mco, male copulatory organ; mv, muscular portion of vagina; o, ovary; oo, oötype; os, oral sucker; pm, posterior microhook; scl, sclerite; sr, seminal receptacle; t, testis; vp, vaginal pore; e, egg; vr, viteline reservoir.

Type-locality. Celestún, Yucatán, Mexico (2051’33”N; $\left.90^{\circ} 24^{\prime} 00^{\prime \prime} \mathrm{W}\right)$.

Site of infection. Gill.

Prevalence and intensity. One fish was infected with 12 worms.

Zoobank registration. FAEBD7B9-2CBD-4353-961AFAEC2814640A (ZOOBANK, 2017).

Etymology. The specific epithet honors Dr. Juan Violante-González, Unidad Académica de Ecología Marina, Universidad Autónoma de Guerrero, Acapulco, Mexico, for advancing our knowledge of marine ichthyoparasitology and ecology.

Description. Measurements based on 12 adult specimens as whole-mounts. Body (excluding haptor) $821(660-950, \mathrm{n}=11)$ long, longer than wide ( $\mathrm{L}: \mathrm{W}=2.6: 1$ ) with maximum body width $315(250-390, \mathrm{n}=11)$ at level of middle of ovary (Figure 1 ). Haptor $205(190-230, \mathrm{n}=11)$ to from the union of body with haptor to midpoint between sucker-sclerite complexes 3 and 3'; 


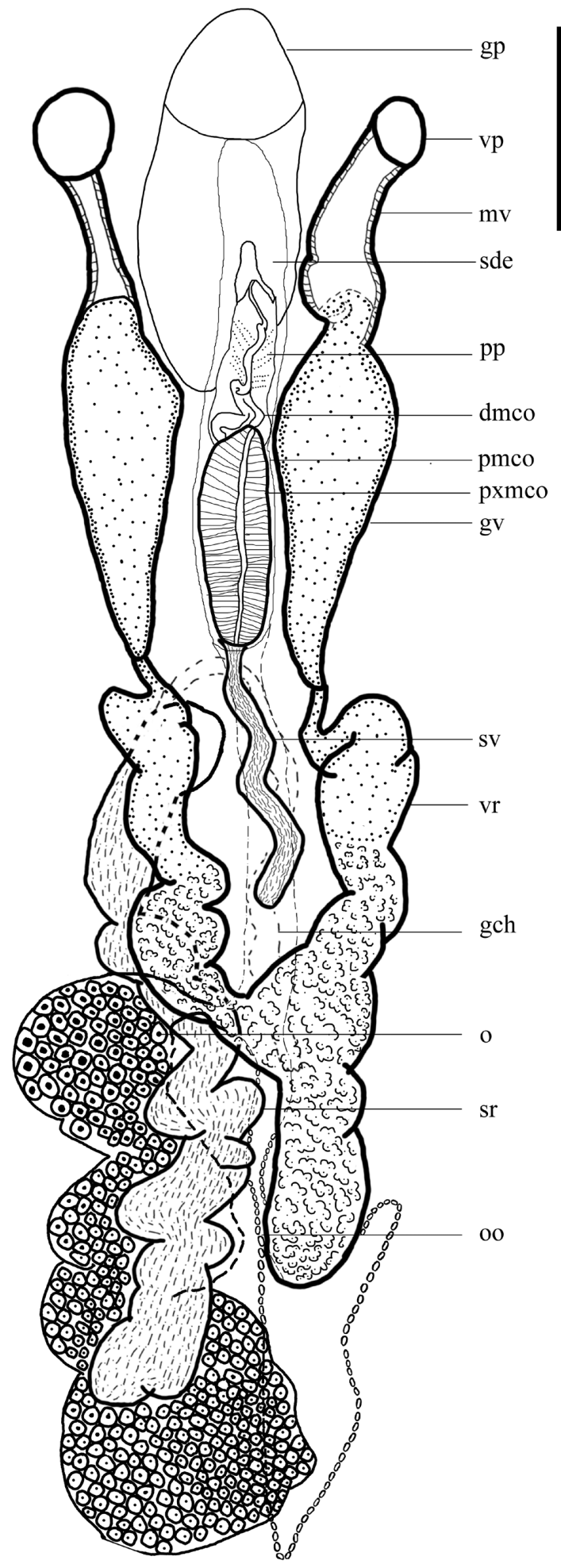

Figure 2. Neonchocotyle violantei n. sp.; detail of the reproductive organs. Scale bar $=75 \mu \mathrm{m}$. Abbreviations: dmco, distal portion of the male copulatory organ; gch, genital canal; gp, genital pore; gv, glandular region of the vagina; mv, muscular region of the vagina; o, ovary; oo, oötype; pmco, pouch of male copulatory organ; pp, pars prostactica; pxmco, proximal portion of the male copulatory organ; sde, sclerotized distal end; sr, seminal receptacle; sv, seminal vesicle; vp, vaginal pore; vr, viteline reservoir.
$754(560-930, \mathrm{n}=9)$ from anterior edge of sucker-sclerite complex 1 and anterior edge of sucker-sclerite complex 3. Sucker-sclerite complexes extensively papillate; papillae distributing in concentric rings on rim of each sucker (Figures 1A, 3B). Sucker-sclerite complex pair 1 sinistral, immediately posterior to body, in anterior portion of haptor (Figures 1A, 5B). Array of non-sclerotized ridges on ventral surface of each sucker-sclerite complex, running perpendicular to shaft of sclerite (Figure 3A). Sucker complexes not significantly different in length (ANOVA: $F=$ 2.25 ; $<\mathrm{F}[5,47,0.05]=2.41)$ but the widths are significantly different (ANOVA: $F=3.67 ;>F[5,47,0.05]=2.42$ ). Sucker one (Figures 1A, 5B) $94(75-105, \mathrm{n}=8)$ long, $75(55-98, \mathrm{n}=8)$ wide; sucker one-prime $104(75-120, \mathrm{n}=10)$ long, $80(63-100, \mathrm{n}=10)$ wide; sucker two $110(100-120, \mathrm{n}=8)$ long, $102(75-130, \mathrm{n}=8)$ wide; sucker two-prime $98(78-110, \mathrm{n}=9)$ long, $86(68-100, \mathrm{n}=9)$ wide; sucker three $103(85-115, \mathrm{n}=8)$ long, $92(65-113, \mathrm{n}=8)$ wide; sucker three-prime $99(70-113, \mathrm{n}=11)$ long, $94(70-113, \mathrm{n}=10)$ wide. Sclerites tip (sclerite hook sensu VAUGHAN \& CHRISTISON, 2012) pointing horizontally inward. Sclerites not significantly different in size (ANOVA: $\mathrm{F}=0.80 ;<\mathrm{F}[5,52,0.05]=2.40$ and $\mathrm{F}=0.51 ;<\mathrm{F}[5,52,0.05]=2.4$ [length and width, respectively]). Shaft of sclerite one (Figures 1A, 1B) 28 (24-31, n = 8) long, $3(2-4, \mathrm{n}=8)$ wide; shaft one-prime $27(23-29, \mathrm{n}=9)$ long, $3(2-5, \mathrm{n}=9)$ wide; shaft two $28(23-31, \mathrm{n}=10)$ long, $3(2-4, \mathrm{n}=10)$ wide; shaft two-prime $28(24-30, \mathrm{n}=9)$ long, $3(3-4, \mathrm{n}=9)$ wide; shaft three $29(26-32, \mathrm{n}=11)$ long, $3(2-4, \mathrm{n}=11)$ wide; shaft three-prime $27(24-31,11)$ long, $3(2-4,11)$ wide. Sclerite hook one (Figure 1B) $32(25-38, \mathrm{n}=6)$ long, $10(8-13, \mathrm{n}=7)$ wide; sclerite hook one-prime $32(25-43, \mathrm{n}=9)$ long, $10(8-13, \mathrm{n}=9)$ wide; sclerite hook two $32(23-43, \mathrm{n}=8)$ long, $8(5-13, \mathrm{n}=9)$ wide; sclerite hook two-prime $32(25-35, \mathrm{n}=7)$ long, $9(8-10, \mathrm{n}=7)$ wide; sclerite hook three $31(25-43, \mathrm{n}=8)$ long, $8(5-13, \mathrm{n}=8)$ wide; sclerite hook three-prime $36(30-43, \mathrm{n}=7)$ long, $9(8-13, \mathrm{n}=8)$ wide. Dorsal haptoral appendix without hamuli $353(158-518, \mathrm{n}=9)$ long, 87 (50-118, $\mathrm{n}=10)$ wide, having two pairs of microhooks (Figure 4). Dextral sucker of the haptoral appendix $54(35-63, \mathrm{n}=9)$ long, $41(28-55, \mathrm{n}=9)$ wide; sinistral sucker of the appendix $58(48-65, \mathrm{n}=9)$ long, $39(25-48, \mathrm{n}=9)$ wide. Anterior pair of microhooks present between the suckers of the appendix; dextral microhook $6(5-8, \mathrm{n}=9)$ long, $3(2-4, \mathrm{n}=9)$ wide; sinistral microhook $6(5-7, \mathrm{n}=8)$ long, $3(2-4, \mathrm{n}=9)$ wide. Posterior pair of microhooks at posterior margin of suckers, one microhook associated with each sucker; dextral microhook $7(6-8, \mathrm{n}=8)$ long, $2(2-3, \mathrm{n}=8)$ wide; sinistral microhook $7(5-8, \mathrm{n}=8)$ long, $2(2-3, \mathrm{n}=7)$ wide. Microhooks narrowly fusiform in ventral view, shallowly cresentic in lateral view. Two anterior glands present, one on each side of anterior body end, lateral to pharynx; ascending ducts continue to openings on anterior margin of body. Contents of glands not observed. Antero-median gland not observed. Mouth $61(35-80, \mathrm{n}=10)$ long, $69(31-90, \mathrm{n}=10)$ wide; oral sucker with many sessile papillae. Pharynx broadly elliptoid, immediately posterior to oral sucker, $37(26-53, \mathrm{n}=10)$ long, $38(25-80, \mathrm{n}=10)$ wide. Bifurcation of ceca $115(85-135, \mathrm{n}=9)$ from anterior end of body. Distal portion of excretory system comprising thin, paired ducts and associated pores; pores marginal, sinistral pore 


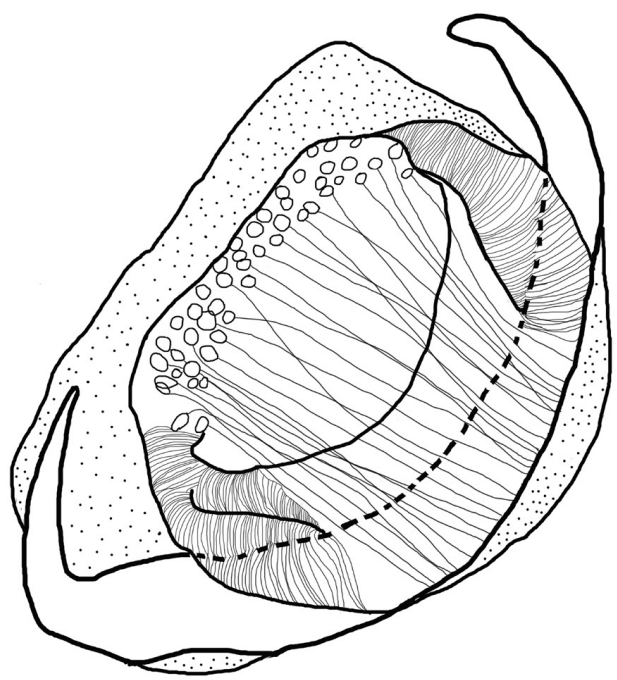

A

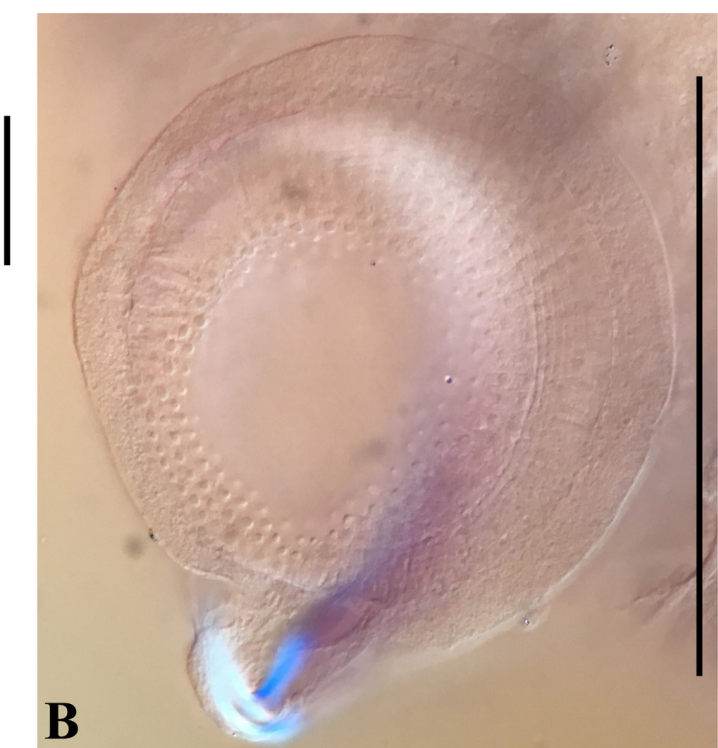

Figure 3. Neonchocotyle violantei n. sp. (A) Sucker-sclerite complex 3, specimen number YUC-99-038-01-1; (B) Papillae rings on sucker-sclerite complex 3. Scale bars: $\mathrm{A}=20 \mu \mathrm{m}, \mathrm{B}=104 \mu \mathrm{m}$.

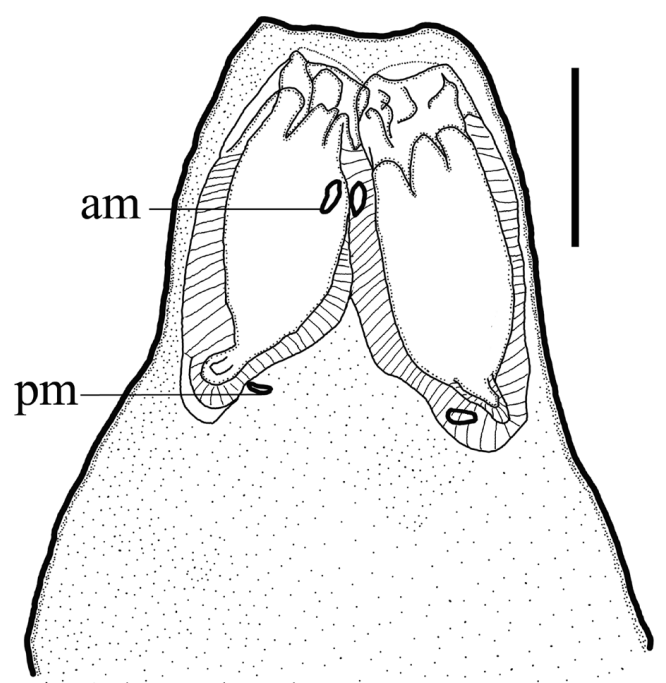

Figure 4. Neonchocotyle violantei n. sp. Haptoral appendix. Abbreviations: am, anterior microhook; pm, posterior microhook. Scale bars: 40 um.

$103(66-128, \mathrm{n}=10)$ from anterior body end; dextral pore $95(57-120, \mathrm{n}=9)$ from anterior body end. Testes $8(5-9, \mathrm{n}=7)$, $58(40-75, \mathrm{n}=26)$ long, $55(33-90, \mathrm{n}=26)$ wide, distributed in a U-shaped pattern. Vasa efferentia and vas deferens not observed. Seminal vesicle elongate, 113 (80-138, $\mathrm{n}=6)$ long, $12(10-13, \mathrm{n}=6)$ wide, extending anterior to proximal male copulatory organ. Pouch of male copulatory organ longer than copulatory organ $181(153-203, \mathrm{n}=9)$ long, $33(25-40, \mathrm{n}=9)$ wide. Male copulatory organ divided in muscular proximal region $72(63-78, \mathrm{n}=9)$ long, $22(13-25, \mathrm{n}=9)$ wide; distal region $44(28-63, \mathrm{n}=9)$ long, $3(3-3, \mathrm{n}=9)$ wide; distal end sclerotized, cone-shaped, $23(15-38, \mathrm{n}=9)$ long, $15(10-28, \mathrm{n}=9)$ wide at base (Figure 2). Genital pore $200(128-238, \mathrm{n}=9)$ from anterior end of body. Ovary $302(225-403, \mathrm{n}=7)$ long, $60(65-75, \mathrm{n}=7)$ wide. Seminal receptacle $327(213-393, \mathrm{n}=8)$ long, $44(40-48, \mathrm{n}=8)$ wide. Vaginal pores extracecal, (Figures 1A, 6B) Glandular portion of dextral vagina $113(68-140, \mathrm{n}=6)$ long, $28(13-45, \mathrm{n}=6)$ wide; muscular portion of dextral vagina $89(68-115, \mathrm{n}=6)$ long, $10(5-18, \mathrm{n}=6)$ wide. Glandular portion of sinistral vagina $113(70-163, \mathrm{n}=6)$ long, $29(13-45, \mathrm{n}=6)$ wide; muscular portion of sinistral vagina $75(48-103, \mathrm{n}=6)$ long, $8(5-13, \mathrm{n}=6)$ wide (Figure 2). Vitellarium follicular, filling extracaecal space from vaginal pores to posterior body end, entering haptor and haptoral appendix. Uterine eggs having two filaments; egg including filaments $334(283-408,4)$ long, egg excluding filaments $113(75-125, \mathrm{n}=6)$ long, $50(45-58, \mathrm{n}=5)$ wide (Figure $1 \mathrm{~A})$. 


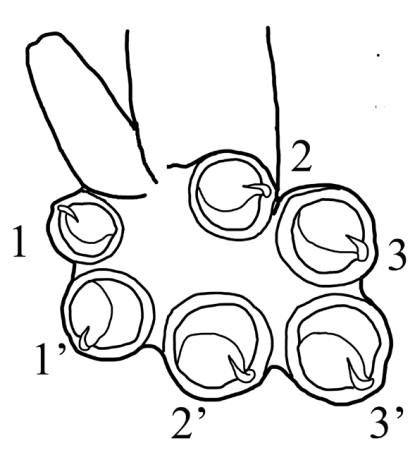

A
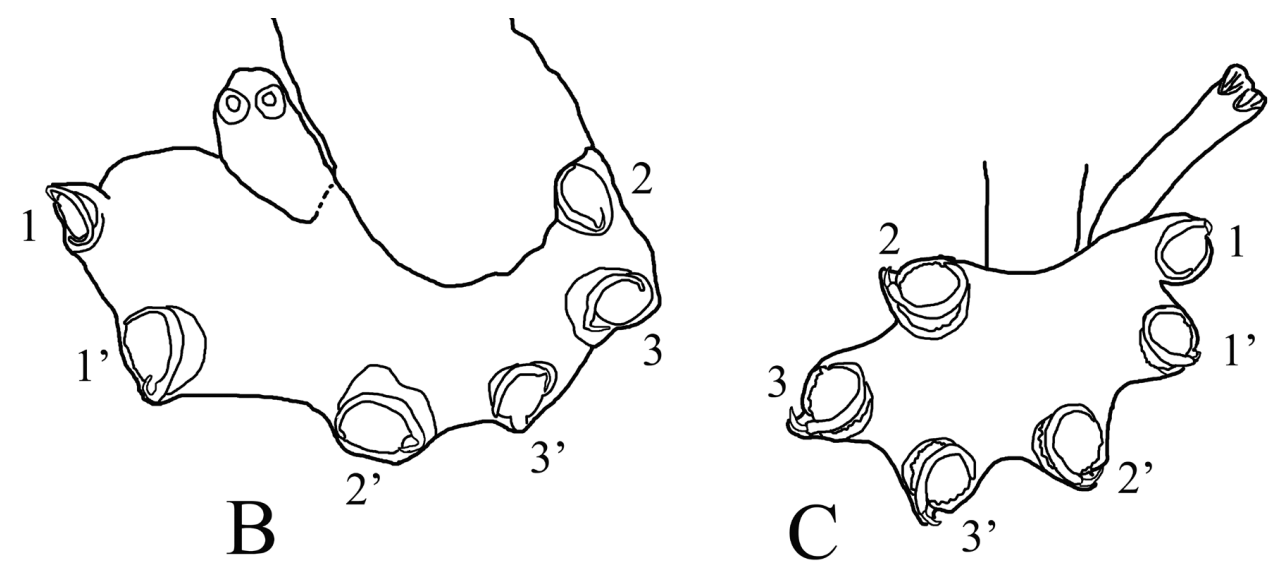

Figure 5. (A) Neonchocotyle pastinacae, ventral view of haptor (modified from KTARI \& MAILLARD, 1972); (B) Neonchocotyle violantei n. sp., ventral view of haptor; (C) Callorhynchocotyle marplatensis, ventral view of haptor (redrawn from VAUGHAN \& CHRISTISON, 2012). Small numbers identify respective sucker-sclerite complexes; complex pares are indicated by numbers 1 to 3, and 1' (1-prime) to 3' (3-prime) (see BOEGER \& KRITSKY, 1989). Haptors not drawn to scale.

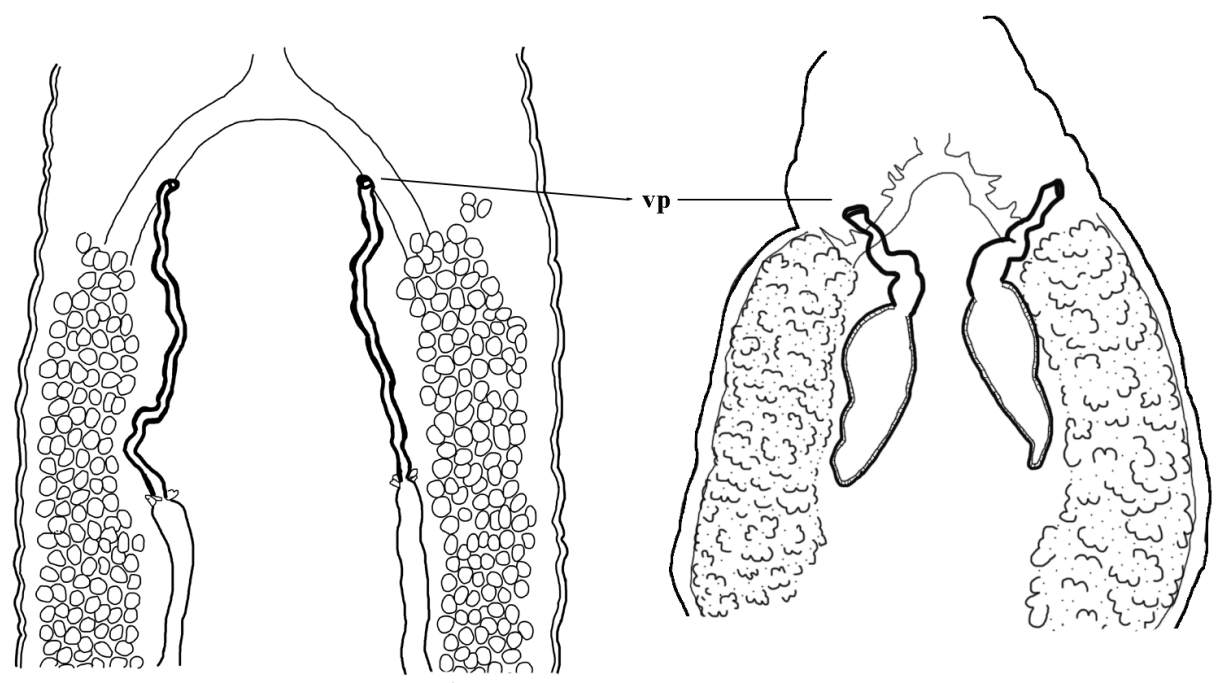

A

B

Figure 6. (A) Neonchocotyle pastinacae; position of the vaginal pores, ventral view (redrawn from KTARI \& MAILLARD, 1972); (B) Neonchocotyle violantei n. sp., position of the vaginal pores, ventral view (holotype). Abbreviations: vp, vaginal pore. Scale bars: $A=200 \mu \mathrm{m}, \mathrm{B}=75 \mu \mathrm{m}$.

\section{Remarks and Discussion}

Neonchocotyle was proposed by Ktari \& Maillard (1972) for Neonchocotyle pastinacae that infects gill of common stingray, Dasyatis pastinaca, from the Gulf of Tunis. Bullard \& Dippenaar (2003), building upon information summarized by Boeger \& Kritsky (1989), furnished a key that distinguished Neonchocotyle from all other hexabothriids by the presence of an asymmetrical haptor, appendix originating from dorsal surface of haptor, sclerites not equally sized, and prostatic region present. These characters, except for the inequality in the size of the sclerites, are present in the specimens that we collected in Mexico, so we have assigned the new species to this genus. However, several features present on the new species had not been described for the genus, although some are present in the description and figures of Ktari \& Maillard (1972). Thus, an emendation of the genus was required.

Boeger \& Kritsky (1989), who were only able to study of paratype from the personal collection of Claude Maillard, remarked that they could not confirm the origin of the haptoral appendix in the specimen of $N$. pastinacae. Specimens of that species were not available to us for study; however, the haptoral appendix of the new species originates from the dorsal haptoral surface, as seen in Callorhynchocotyle Suriano \& Incorvaia, 1982 and Epicotyle Euzet \& Maillard, 1974 (SURIANO \& INCORVAIA, 1982; EUZET \& MAILLARD, 1974; VAUGHAN \& CHRISTISON, 2012).

Ktari \& Maillard (1972) mention that the vas deferens formed a loop before it joined the male copulatory organ. Boeger \& Kritsky (1989) also mention this in their diagnosis of the genus, but neither they nor the author of the original description depicted 
this feature in their figures. We could not differentiate a looped section of the vas deferens in our specimens, so we did not mention it in our diagnosis and it was not illustrated.

Despite the increase in the number of studies of the phylogenetic relationships of monogeneans using morphological features (BOEGER \& KRITSKY, 1989, 1993; CHISHOLM et al., 1995; WHITTINGTON, 2004), there still exist confusion between characters (morphological features) and the states (derived forms) of those characters. All of the states of a particular character are homologous. Thus, all of the states should be referred to by the same name regardless of differences in appearance (derived condition). An example is the use of vasa efferentia to refer to ducts that carry sperm from the testis. The structure that carries sperm from testis in every species of monogenean (the vas efferens) is homologous a should be referred to by the same name even though its derived form is a dilated, glandular-wall (BULLARD \& DIPPENAAR, 2003) or it is a thin non-glandular wall (GLENNON et al., 2005). Theses are forms (thing walled, glandular, or looped) of the same homologous structure, so they should be referred to by the same name (vas efferens). It is confusing to change the name of the structure depending on its derived condition.

Neonchocotyle violantei n. sp. is the second species of the genus. One remarkable difference between $N$. violantei and $N$. pastinacae is body size. The body of $N$. violantei $\mathrm{n}$. sp. is smaller than that of $N$. pastinacae (821 long x 315 wide vs. 6580 x 1041 , respectively). Furthermore, the new species can be distinguish from $N$. pastinacae by having two anterior glands on each side of the body, submarginal (extracaecal) vaginal pores (Figure 6B) (intracaecal in $N$. pastinacae (Figure 6A)), and the number of testes. Two pairs of microhooks, similar to those depicted for Squalonchocotyle sp. by Bychowsky (1957) are present in the new species (not described for $N$. pastinacae). The microhooks of the new species are narrowly fusiform in ventral view, shallowly cresentic in lateral view; this form was described as "buttonhole" by Bychowsky (1957; see their figure 290); all microhooks could be distinguished as sclerotized structures. Hamuli were not found in the new species but are present in $N$. pastinacae. We could not discern any holes in the area where the hamuli are located in any of our specimens which might indicate that they had been lost and it is unlikely that they would have been lost in all 12 specimens.

Not direct comparisons can be made between the sizes of the haptors of the two species because Ktari \& Maillard (1972) did not mention at which point they measured the haptor. However, the haptor of the new species is smaller than the measurements given for $N$. pastinacae ( 205 x 754 vs. 874 x 1,466 wide). Other differences in sizes included the pharynx ( 37 x 38 vs. $110 \times 75)$, the pouch of the male copulatory organ (181 long vs. 536), the ovary (302 vs. 582 ), and the eggs (113 vs. 135).

The number of testes is different in each species. Ktari $\&$ Maillard (1972) did not give the number of testes for N. pastinacae, but in their figure (KTARI \& MAILLARD, 1972; their figure 1) the number of the testes appears to be more than 30 ; the mean number of testes of the new species, $N$. violantei, is between 8 and 9 . The terminal end of the male copulatory organ of the new species is sclerotized; scleritization was no mentioned by Ktari \& Maillard (1972) for N. pastinacae, and its presence or absence in that species could not be confirmed.
Ktari \& Maillard (1972; their figures 1, 12) described and depicted that the proximal portion of the vaginae are connected to the anterior branches of the vitelline reservoir, and that the transverse vitelline ducts connect to the Y-shaped vitelline reservoir. The posterior region of the reservoir joins to the oviduct. The transverse ducts are dorsal and were obscured in our specimens.

Neonchochotyle violantei n. sp. is the third helminth reported from Pseudobatos lentiginosus in the Gulf of Mexico. Rodríguez-Ibarra et al. (2011) reported Paramonilicaecum-type metacercariae (Digenea) from Laguna de Tampamacho on the northern Gulf coast of Veracruz, Mexico, and Vardo-Zalik \& Campbell (2011) described Acanthobothrium lentiginosum Vardo-Zalik \& Campbell, 2011 from the south Texas coast, Gulf of Mexico. The present report is from the opposite (eastern) side of the Gulf of Mexico, suggesting that much remains to be learned about the helminths of $P$. lentiginosus.

Key to the genera of Hexabothriidae Price, 1942

All currently publish keys to the Hexabothriidae are incomplete because they do not include all currently known taxa for many reasons. Of the must often uses keys, that of Yamaguti (1963) is outdated because it does not include the taxa described since that time and his systematic arrangement differs from current hypotheses. The more recent key of Bullard \& Dippenaar (2003) is consistent with current hypotheses but lack taxa because there was insufficient morphological information or because they were described more recently. The key of Yamaguti (1963) lacks eight more recently described genera and the other two keys lacked two genera, one for lack of information and one because it was described more recently than those publications (BOEGER \& KRITSKY, 1989; BULLARD \& DIPPENAAR, 2003). Two genera that often are excluded from studies, Pseudohexabothrium Brinkmann, 1952 and Pristonchocotyle, are included in our key. The key presented herein is not base on a phylogenetic hypothesis for the family, but it includes all genera known to date.

Pristonchocotyle was excluded in the systematic treatments of Boeger \& Kritsky (1989) and Bullard \& Dippenaar (2003), perhaps because the description of its type species $P$. intermedia Watson \& Thorson, 1976 was incomplete. For example, in the figures of that paper (WATSON \& THORSON, 1976) it is not clear whether the haptor is symmetrical or asymmetrical and we were not able to study the slides and review this character. Watson \& Thorson (1976, p. 633) mention that the, "Anterior hook measures 154 to 224 (189) long by 29 to 46 (39) wide, remaining hooks appear in a row [...]", but the drawing of the holotype shows only three sucker-sclerite complexes and they are not labeled, so the normal position of each cannot be determined. The haptoral appendix is shown on the upper margin of the drawing of the haptor (WATSON \& THORSON, 1976; their figure 17) although it was not specified in the description. It is not clear in their drawings whether it arises laterally or dorsolateral. Ogawa's (1991) description of Pristonchocotyle papuensis Ogawa, 1991 reported that the haptoral appendix originates dorsally and clearly depicted the arrangement of the haptoral sucker-sclerite complexes. This and other information in the description allowed the genus to be included in the key. The only other genus having vaginae that join medially (X-shaped) is Rhinobatonchocotyle but it differs from Pristonchocotyle by lacking a seminal receptacle. 


\section{Key}

1a. Haptor symmetrical. 2

b. Haptor asymmetrical. 10

2a. Male copulatory organ armed with spines. 3

b. Male copulatory organ unarmed. 4

3a. Haptor symmetrical, with sucker-sclerite complexes arranged in a lineal pattern. Hexabothrium Nordmann, 1840

b. Haptor symmetrical, with sucker-sclerite complexes arranged in a triangular pattern. Dasyonchocotyle Hargis, 1955

4a. Egg with two polar filaments. 5

b. Egg with one polar filament. Pseudohexabothrium Brinkmann, 1952

5a. Vaginae not differentiated into two types of tissue. $\mathbf{6}$

b. Vaginae differentiated into two types of tissue. 7

6a. Male copulatory organ with elongate distal portion well demarcated from proximal portion. Protocotyle Euzet \& Maillard, 1974

b. Male copulatory organ not demarcated into distinct proximal and distal portions. Rajonchocotyle Cerfontaine, 1899

7a. Distal portion of male copulatory organ ovate.

Erpocotyle van Beneden \& Hesse, 1863

b. Distal portion of male copulatory organ elongate. $\mathbf{8}$

8a. Dilated vasa efferentia with glandular wall absent.

Squalonchocotyle Cerfontaine, 1899

b. Dilated vasa efferentia with glandular wall present. 9

9a. Vasa efferentia dilated distally and narrow for rest of length.

Branchotenthes Bullard \& Dippenaar, 2003

b. Vasa efferentia narrow for entire length (not dilated distally).

Mobulicola Patella \& Bullard, 2013

10a. Haptoral appendix originating from margin of haptor. 11

b. Haptoral appendix originating from dorsal surface of haptor. 14

11a. Haptoral appendix without hamuli

Parabeteronchocotyle Mayes, Brooks, \& Thorson, 1981

b. Haptoral appendix armed with hamuli. 12

12a. Vaginae run parallel until joining vitelline commissure.

Heteronchocotyle Brooks, 1934

b. Vaginae fuse at midline of body but separate before joining vitelline commissure (form X-shaped structure) (BOEGER \& KRITSKY, 1989; their figure 18). 13

13a. Seminal receptacle absent. Rhinobatonchocotyle Doran, 1953

b. Seminal receptacle present. Pristonchocotyle Watson \& Thorson, 1976

14a. Distal portion of cirrus ovate. Callorhynchocotyle Suriano \& Incorvaia, 1982

b. Distal portion of cirrus elongate. 15

15a. Haptoral appendix originates between sucker-sclerite complexes 1' and 2.'

\section{Epicotyle Euzet \& Maillard, 1974}

b. Haptoral appendix originates between sucker-sclerite complexes 1 and 2.

Neonchocotyle Ktari \& Maillard, 1972. 16

\section{Acknowledgements}

We acknowledge Luis García-Prieto and Scott L. Gardner (CNHE and HWML, respectively) for the loan of specimens and providing literature. We also thank Kazuo Ogawa, Director of the Meguro Parasitological Museum, Meguro, Tokyo, for providing a copy of the description of Pristonchocotyle papuensis for the library of the HWML, which then forwarded a copy to us.

\section{References}

Boeger WA, Kritsky DC. Phylogeny and a revised classification of the Monogenoidea Bychowsky 1937, (Platyhelminthes). Syst Parasitol 1993; 26(1): 1-32. http://dx.doi.org/10.1007/BF00009644.

Boeger WA, Kritsky DC. Phylogeny, coevolution, and revision of the Hexabothriidae Price, 1942 (Monogenea). Int J Parasitol 1989; 19(4): 425-440. http://dx.doi.org/10.1016/0020-7519(89)90099-4.

Bullard SA, Dippenaar SM. Branchotenthes robinoverstreeti n. gen. and n. sp. (Monogenea: Hexabothriidae) from the gill filaments of the bowmouth guitarfish, Rhina ancylostoma (Rhynchobatidae), in the Indian Ocean.J Parasitol 2003; 89(3): 595-601. PMid:12880262. http://dx.doi. org/10.1645/0022-3395(2003)089[0595:BRNGAN]2.0.CO;2.

Bychowsky BE, editor. Monogenetic trematodes: their systematics and phylogeny. Moscow-Leningrad: Izdatel'stvo Akademiya Nauk SSSR; 1957. Translation.

Chisholm LA, Wheeler TA, Beverley-Burton M. A phylogenetic analysis and revised classification of the Monocotylidae Taschenberg, 1879 (Monogenea). Syst Parasitol 1995; 32(3): 159-191. http://dx.doi. org/10.1007/BF00008827.

Ciudad de México. Secretaría de Medio Ambiente y Recursos Naturales - SEMARNAT. Programa de manejo: Reserva de la Biosfera Ría Celestín [online]. Ciudad de México: SEMARNAT; 2000 [cited 2004 Jan 19]. Available from: http://ramsar.conanp.gob.mx/docs/sitios/FIR_RAMSAR/ Yucatan/RB_Ria_Celestun/Reserva\%20de\%20la\%20Biosfera $\% 20$ R\%C3\%ADa\%20Celestún.pdf

Clopton RE. Standard nomenclature and metrics of plane shapes for use in gregarine taxonomy. Comp Parasitol 2004; 71(2): 130-140. http:// dx.doi.org/10.1654/4151.

Euzet L, Maillard C. Les Monogènes Hexabothriidae Price, 1942: historique, systématique, phylogenèse. Bull Mus Natl Hist Nat 1974; 206: 113-141.

Glennon V, Chisholm LA, Whittington ID. Branchotenthes octohamatus sp. n. (Monogenea: Hexabothriidae) from the gills of the southern fiddler ray, Trygonorrhina fasciata (Rhinobatidae) in South Australia: description of adult and larva. Folia Parasitol 2005; 52(3): 223-230. PMid:16270803. http://dx.doi.org/10.14411/fp.2005.030.

Kheddam H, Justine JL, Tazerouti F. Hexbothriid monogeneans from the gills of deep-sea shark off Algeria, with the description of Squalonchocotyle euzeti n. sp. (Hexabothriidae) from the kitefin shark Dalatias licha (Euselachii, Dalatiidae). Helminthologia 2016; 53(4): 354-362. http:// dx.doi.org/10.1515/helmin-2016-0034.

Ktari MH, Maillard C. Neonchocotyle pastinacae n.g.- n.sp. (MonogeneaHexabothriidae) parasite de Dasyatis pastinaca dans le golfe de Tunis: description de 'l'adulte et de la larve. Ann Parasitol Hum Comp 1972; 47(2): 181-191. http://dx.doi.org/10.1051/parasite/1972472181. 
Ogawa K. Ectoparasites of sawfish, Pristis microdon, caught in freshwaters of Australia and Papua New Guinea. In: Shimizu M, Taniuchi T, editors. Studies on Elasmobranchs Collected from Seven River Systems in Northern Australia and Papua New Guinea. Tokyo: University of Tokyo; 1991. p. 91-102. (Nature Culture; vol. 3).

Patella R, Bullard SA. Hexabothriids of devil rays (Mobulidae): new genus and species from gills of Mobula hypostoma in the Northern Gulf of Mexico and redescription of a congener from Mobula rochebrunei in the Eastern Atlantic Ocean. J Parasitol 2013; 99(5): 856-867. PMid:23641805. http://dx.doi.org/10.1645/12-153.1.

Price EW. North American monogenetic trematodes. V. The family Hexabothriidae, n. n. (Polystomatoidea). Proc Helminthol Soc Wash 1942; 9(2): 39-56.

Pulido-Flores G, Monks S. Monogenean parasites of some elasmobranchs (Chrondrichthyes) from the Yucatán Peninsula, México. Comp Parasitol 2005; 72(1): 69-74. http://dx.doi.org/10.1654/4049.

Rodríguez-Ibarra AE, Monks S, Pulido-Flores G. Metacercarias del tipo Paramonilicaecum (Digenea: Didymozoidae), parásitos accidentales de elasmobranquios (Elasmobranchii) del golfo de México e identificación de metacercarias (Didymozoidae) de la Colección Nacional de Helmintos. Rev Mex Biodivers 2011; 82(2): 705-708.

Suriano DM, Incorvaia IS. Sistemática y biología de Callorhynchocotyle marplatensis gen. et sp. n. (Monogenea: Polyopisthocotylea) parásita de las branquias de Caliorhynchus cailorhynchus (Linné, 1758) Garman, 1904 (Pisces, Holocephali) de la región costera de Mar del Plata. Comun. Mus. Argent. Cienc. Nat. "Bernardino Rivadavia"1982; 2: 19-32.
The Official Registry of Zoological Nomenclature International ZOOBANK. Neonchocotyle violantei Quiterio-Rendon Guadalupe, Monks Scott \& Pulido-Flores Griselda, 2018 [online]. Commission on Zoological Nomenclature; 2017 [cited 2017 Sept 14]. Available from: http://zoobank. org/E4CE2F06-00FD-4EA8-9DDA-9D15293B982A

Vardo-Zalik AM, Campbell RA. Five new species of Acanthobothrium van Beneden, 1849 (Cestoda: Tetraphyllidea) in elasmobranchs from the northwest Atlantic and Gulf of Mexico with the first records from smooth-hound sharks and guitarfish. Zootaxa 2011; 2838: 41-64.

Vaughan D, Christison K. Towards addressing the current state of confusion within the Hexabothriidae Price, 1942 (1908): Callorhynchocotyle Suriano \& Incorvaia, 1982 (Monogenea: Hexabothriidae) re-visited, with the preliminary evaluation of novel parameters for measuring haptoral armature of hexabothriids. Zootaxa 2012; 3229: 1-34.

Watson DE, Thorson TB. Helminths from elasmobranchs in central American fresh waters. In: Thorson TB, editor. Investigations of the Ichthyofauna of Nicaraguan Lakes. Lincoln: School of Life Sciences, University of Nebraska-Lincoln; 1976. p. 629-640.

Whittington ID. The Capsalidae (Monogenea: Monopisthocotylea): a review of diversity, classification and phylogeny with a note about species complexes. Folia Parasitol 2004; 51(2-3): 109-122. PMid:15357390. http://dx.doi.org/10.14411/fp.2004.016.

Yamaguti S. Systema Helminthum: Monogenea and Aspidocotylea. New York: Wiley Interscience Publications; 1963. 